\title{
Türk Dili ve Edebiyatı Bölümü ve Öğretmenliği Programlarında Medyanın Yeri*
}

\author{
Ayşe Derya ESKIMEN*
}

Öz

Günümüz eğitim anlayışında esas olan öğrencinin derse dikkatini çekmek, bilgiyi daha somut, kalıcı hâle getirmek ve öğrencilerin birtakım becerilerini geliştirmektir. Bu anlamda, eğitimde filmlerin ve diğer başka medya araçlarının kullanımı bu kazanımların sağlanmasına katkı sağlayarak, bilgiyi daha etkili ve kalıcı hâle getirmeye yardımcı olmaktadır. Çalışmada özellikle üzerinde durulan medya alanı, filmler olmuştur. Filmler, tıpkı edebiyat gibi insanların anlatma ve anlama gereksinimleri dolayısıyla ortaya çıkmıştır. Nitekim her iki sanat dalının birtakım benzerlikleri söz konusudur ve edebiyat, güzel sanatların bir diğer dalı olan sinema ile etkileşim içerisindedir. Edebî metinler ve filmlerin bir arada ele alınması yoluyla öğrenciler, hangi seviyede olursa olsun empati kurma, eleştirel düşünme, yaratıcı düşünme, iletişim kurma, araştırma, problem çözme, karar verme, görsel okuma gibi birtakım katkılar elde etmektedir. Dolayısıyla denilebilir ki, sinema ve edebiyat ilişkisi eğitim öğretimin her seviyesinde ele alınmalı, bu ilişkiye yönelik derslere ögretim programlarında yer verilmelidir. Tüm bunlara yönelik olarak araştırmada, Türk Dili Edebiyatı ve Türk Dili ve Edebiyatı Öğretmenliği lisans programlarında sinema, edebiyat ve medyaya yönelik derslere yer verilme durumu ele alınmıştır.

Anahtar Kelimeler: Sinema, medya, eğitim, Türk dili ve edebiyatı lisans programları

* Dr. Öğr. Üyesi, Kütahya Dumlupınar Üniversitesi, Eğitim Fakültesi, Türkçe Eğitimi Ana Bilim Dalı, Kütahya, Türkiye. Elmek: deryaeskimen@hotmail.com https://orcid.org/0000-0002-9155-9971 


\title{
The Place of Media in The Department of Turkish Language and Literature and Education Programs
}

\begin{abstract}
The essential approach to today's understanding of education is to draw student attention to the subject being taught, to make the knowledge more tangible and permanent and to develop a set of skills of the students. In this sense, the usage of films and other media instruments in education helps to make the knowledge more effective and permanent by contributing to provide these objectives. The media medium particularly mentioned in the study has been the films. Films emerged due to people's needs of telling and understanding just like literature. Thus, a set of similarities related to both fields of art is in question and literature in interaction with cinema, which is another field of fine arts. No matter whatever their level is, students get a set of contributions such as establishing empathy, critical thinking, creative thinking, communicating, searching, problem solving, decision making, and visual reading when literary texts and films are used together. Thus, it can be said that the relationship of cinema and literature should be considered at each level of education and teaching, and courses related to this relationship should be included in teaching programs. In the research related to all the aforementioned items, the issue regarding the inclusion of the courses related to cinema, literature and media in the undergraduate programs of Turkish Language Literature and Turkish Language and Literature Education has been considered.
\end{abstract}

Keywords: Cinema, media, education, Turkish language and literature undergraduate programs 


\section{Extended Abstract}

When language and literature education of our country's secondary education and universities are examined, it cannot be said that the use of films and other media elements in courses is very common within the education process. The courses of the language and literature departments of many universities include theater-related courses, while film-related courses are only rarely. However, knowing how the narrative tools and aesthetics of a film can be handled in a way that goes beyond a normal viewing experience and claims to be scientific cannot be considered separate from knowing how the narrative of a novel or theatre play can be solved -especially considering that a film is the world's number one narrative media in terms of consumption (Kayaoğlu, 2016:6). Therefore, this situation can get extended through secondary education programs and textbooks. As a matter of fact, the 2018 Turkish Language and Literature course curriculum should give place to visual communication tools in teaching and practices; and slides, computer, television, interactive board, Internet, Educational Data Processing Network practices etc. should be used effectively. It is said that: "Such materials as documentary and film should be used related to gains." The curriculum of high school which is the previous step of university education can give place to critical film readings, literature and cinema, literature and media courses; so that we can raise individuals who are able to discuss whatever they hear and think and who are ready for attending university. In fact, according to Sedat Sever (2002 and 2007), combining expression power of literature with resources of fine arts improves students' imagination and mind power; in other words, it improves their creativity. In this sense, it needs to be stated that the universities aiming to raise Turkish Language and Literature teachers can give more place to the courses of critical film readings, film criticism and analysis, film literature, literature and cinema, literature media and communication. Accordingly, gains of the courses on cinema, literature and 
media and the courses which are directly related to these fields and which are included in the curriculum of the universities, names of which are given place in the study, are listed as follows. Students taking these courses

- focus on literature outcomes, techniques and types of films, film theory and film criticism,

- analyze a film with cultural and different critical approaches and they learn to watch it as a text.

- discover similar and different aspects of literature, visual arts and cinema,

- compare the relationship between literature and cinema, the interaction of these two fields, the works adapted from the screenplays and films,

- analyze the films adapted from the literature,

- get to know sample adaptations made on literature works transferred to cinema well and carry out analyzes accordingly,

- learn what variables literary works (novel-story-mesnevi) are subject to when turning into scenario,

- learns how to construct the dramatic structure of this scenario by using narrative techniques.

- improve their writing skills and gain the skill of thinking visually and expressing their opinion about the scenario and scriptwriter of a film they watch. Besides, it is important to get them have interpretation and writing trials. They interpret some writers' opinions on cinema, - gain critical thinking skill by looking at the film analysis of different periods and themes in order to analyze and evaluate films in terms of their content and forms, rather than considering films an entertainment tool. Thus, they comprehend and evaluate films with their social and cultural influences and interactions in more detail, - get an idea of film theories, filmmaking process, type and language of films, how to carry out content analysis of a film as visual text, and how to carry out critical readings of films, and improve their awareness accordingly. 


\section{Method}

\section{Aim and Importance of Research}

"It is known that the use of films in educational and educational activities in technologically and economically developed countries dates back to the first quarter of last century" (Demircioğlu, 2007: 77). A sound script, an interesting and intricate fiction, well-crafted characters, powerful depictions, and a cinema that uses the details of the place to feed on literary genres are reaching an artistic successful film. Literary genres such as poetry, essays, stories, and especially novels are often adapted to cinema (İnce Yakar 2011). In this context, in order to determine whether the courses that can relate literature and cinema are included in the curriculums of universities, in the study, Turkish language literature and Turkish language and literature teacher education programs have been taken into consideration in the field of cinema, literature and media courses.

\section{Collection And Analysis Of Data}

The research is a scripted study performed using qualitative data analysis techniques because it depicts an existing situation based on a document review. Document review was carried out in the data collection. "Document review covers the analysis of written materials containing information about the targeted cases or cases" (Yıldırım and Şimşek 2008: 187). The study document consists of the courses of the foundation and state universities in the Higher Education Council Web page, the courses of the Bologna Information System suite of Turkish language and literature and Turkish language and literature teaching in 2018-2019, and the courses of the diploma program of the bologna information system. When evaluating the data obtained, the following stages were followed: (1) accessing documents, (2) checking authenticity, (3) understanding documents, (4) analyzing data and (5) using data" (Forster, 1995 cited by Yildirim and Şimşek 2008: 193). 



\section{Giriş}

\section{Medya ve Sinema}

Çalışma, genel olarak medya ve kapsamında yer alan sinema-film ilişkisi üzerinden ele alındığı için öncelikle medya kavramı ve alanına yönelik çeşitli tanımlara bakmak gerekir. Gürsel Aytaç (2005), medya kavramını kitle iletişim aracısı olarak tanımlamıştır. "Etimolojik olarak aracılar demek olan medya, günümüzde tekil kullanıma bürünmüş, genellikle kitle iletişim aracısı ya da arac1 televizyon için söz konusu olmuştur (Aytaç, 2005: 9). Sinemanın kitle iletişim aracı olduğu genel bir kabuldür (Uğurlu, 1992: 146). Medya kavramının neyi ya da neleri kapsadığına yönelik bir karmaşanın söz konusu olduğu yadsınamaz. Şöyle ki: "Günümüzde yoğun olarak kullanılmasına rağmen 'medya' kavramının sınırları ve kapsamı belli değildir. Örneğin, "televizyon medyası" denmekte, bunun yanında; yazılı basın, radyo ve televizyon (hatta internet) başta olmak üzere hepsini kastetmek için yine "medya" kavramı kullanılmaktadır...Medya genel anlamda kitle iletişim araçlarını ve ortamları kapsamaktadır (Kocadaş, 2006: 5). Şu bilinen bir gerçektir ki "Başta TV-Radyo, onları daha gerilerde izleyen sinema, medyanın en yüksek gücünü temsil etmektedir (Kaçar Gitmez, 1999: 23) ve "Medya olarak adlandırılan basın ve yayın organları, toplumun değişmesinde, gelişmesinde ve şekil kazanmasında oldukça önemli bir rol oynamaktadır (Ekici, 2004: 181). Sinemayı medya içerisinde değerlendiren isimlerden Ersel Kayaoğlu (2016), sinemayı hem "çok geniş kitle tarafindan alımlanan bir medya", hem de "dünyanın bir numaralı anlatma medyası" olarak görür. "Filmin çok geniş kitle tarafından alımlanan bir medya olduğu göz önünde bulundurulduğunda mitler yaratması ve dünyayı yorumlaması üzerinden neredeyse tüm insanlığın gerçeklik kontrüksiyonu ve sosyalizasyonu üzerinde etkisi bulunuyor" (Kayaoğlu, 2016:5). Tüm bunlardan hareketle çalışmada sinema, Kayaoğlu'nun ifadesiyle "medyanın en yüksek gücünü temsil etmesi” bakımından ve aynı zamanda eğitimde kullanılabilen bir araç olması yönleriyle çalışmada esas olarak üzerinde durulan ve edebiyatla ilişkilendirilen medya alanı olmuştur. "Başlangıçta teknik bir buluş 
olarak ortaya çıkan sinema, sonraları sinema sanatçıları aracıllı̆ıyla kendine özgü dilini ve anlatım yöntemlerini bularak ve geliştirerek 7. sanat olarak sanat tarihindeki yerini almıştır" (Vardar, 2012: 1).

\section{Sinema-Edebiyat-Ĕgitim İlişkisi}

Bağımsız bir sanat dalı olup olmadığı hâlâ tartışılsa da sinemanın felsefe, tarih, politika, mantık, astronomi, etnoloji, sosyoloji, kültür bilimi, din bilimi, mitoloji, teknoloji gibi alanların yanında müzik, dans, grafik, resim, heykel, tiyatro ve özellikle edebiyatla ilişkisi, herkesçe kabul edilmektedir. Sinemadan daha eski bir sanat olan edebiyatın etkisi, senaryo yazımı ve edebi eserlerin filme uyarlanması kapsamında incelenmektedir (Özdemir, 2012: 217). Kayaoğlu (2016), 1970'lerden başlayarak Almanya' da edebiyat biliminin içinden medya bilimi olarak adlandırılan bir disiplin ortaya çıktığını ifade eder ve edebiyat bilimcilerin kaleme aldığ 1 film ve televizyon çözümlemesine giriş niteliğindeki çalışmaların da yine bu yıllara dayandığını belirtir. Şöyle devam eder: "Batı üniversitelerinde edebiyat bilimi bölümleriyle sıkı bağları bulunana medya bilimi bölümleri de yine iletişim toplumu söyleminin yaygınlaştı̆̆ bu dönemden itibaren açılmaya başlad. Bu türden filolojik medya çözümlemesi yaklaşımı, geniş anlamda bir metin tanımından hareketle, diğer medyanın içeriklerinin de tıpkı edebiyat medyasının ürünleri gibi bir metin olarak okunması gerektiği anlayışına dayanıyor” (s. 16).

Edebiyat ile sinema birbiriyle benzer ve farklı işlevleri olan alanlardır. “...sinema ve edebiyat, iletişim araçları olarak toplumda haber ve bilgi sağlama, toplumsallaştırma, güdüleme, tartışma ortamı yaratma, eğitim, eğlendirme, bütünleştirme, kültürün gelişmesine katkı işlevlerini birbirlerinden bağımsız olarak görürler" (Uğurlu 1992: 146). Bunun yanı sıra Sıddık Akbayır (2014), sinema ile edebiyatın ortaklığı ile ilgili edebiyatta kalem sinemada kamera, edebiyatta okuma filmde seyretme, edebiyatın bireysel bir üretim sinemanın kolektif bir çalışma olduğuna değinir. Sinemayı, edebiyat dilinin görsel dile çevrilmesi olarak ifade eder. Ersel Kayaoğlu da (2016) benzer bir ifadeyle, filmin edebiyattan farkının görüntünün ve sesin etkileme gücüyle izleyiciye duyguları çok daha yoğun biçimde yaşatabilmesi olduğunu dile getirir. Tuncay Yüce ise (2005), edebiyat ve sinemanın etkileşim içerisinde olan iki sanat dalı olmalarını biçim- 
içerik ilişkisinden hareketle aktarır: "Sanat, biçim-içerik ilişkisinin birlikteliğiyle var olmaktadır. Biçimsel öğelerle içeriksel öğelerin yoğrulması sanat yapıtının oluşmasını sağlar." İki farklı sanat dalının, birlikteliğinin benzer bazı içeriksel ve biçimsel özellikler taşıdığını anlatım dillerinin bazı ortak özellikleri aracıllı̆ıyla da etkileşim içerisinde olduklarını ifade eder. Çetin (1999) tarafindan romanın sinemaya uyarlanmasına yönelik hazırlanan doktora tezinde roman ile sinemanın başlıca benzerliklerinin konu, öykü anlatma, dramatik yapı; farklılıklarının ise sözcük-görüntü ayrımı, bakış açış, zaman olduğu üzerinde durulur ve bu benzerlikler, farklılıklar ayrı ayrı açıklanır (s.81-89).

Sinema ve edebiyat ilişkisine eğitim açısından bakılacak olursa; Sinema filmlerinin, çeşitli konuların ve kavramların yansıtılmasında, teori uygulamalarının gösterilmesinde, geleneksel yöntemlerden çok daha fazla güdüleyici ve canlandırıcı bir pedagojik malzeme kaynağı sağladığı da gözlemlenmektedir. Özellikle 1970'lerden sonra video, DVD ve internetteki gelişmelerle bu tür kavramsal filmlerin eğitimde kullanılması çok büyük ölçülerde artmıştır (Birkök, 2018: 8). $\mathrm{Bu}$ anlamda, derslerde kullanılabilecek filmler ve bunların analizinin her eğitim seviyesinde, öğrencilerin yaratıcı ve eleştirel düşünme becerilerinin gelişmesine katk1 sağladığı çeşitli çalışmalarda da (Öztaş 2007; Demircioğlu 2007; Birkök, 2008; Arıkan 2009; Derelioğlu ve Şar 2010; İnce Yakar 2011; Kaşkaya 2013; Keleş 2017; İnce Yakar 2017; Eskimen 2018a, Eskimen 2018b) dile getirilmiştir. Filmler, okullarda ve sınıf ortamında kullanılabilecek doğrudan bir eğitim aracı oldukları gibi aynı zamanda seyircisine pek çok konuda bilgi veren dolaylı ve uzaktan eğitim aracıdırlar (Wegner 1977: 6 akt. İnce Yakar 2011).

\section{Dil-Edebiyat Derslerinde Filmleri Kullanmanın Faydaları}

Görsel ve işitsel materyaller öğrenmenin kalıcı olmasını sağlama, öğrencinin birden fazla duyu organına seslenme, ilgi ve dikkatini çekme, kavramları ve konular1, somutlaştırarak basitleştirme ve dolayısıyla öğrenmeyi kolaylaştırma açılarından önemli bir yere sahiptir. "Örneğin, video filminin kısa bir sahnesinde pek çok mesaj bulunabilir. 3-5 dakika süren kısa bir programa bir saatlik ders sığdırılabilir” (Demirel 1993: 97). "Günümüz eğitim-öğretiminde öğrenenin birden fazla duyusuna hitap etmek, öğrenciyi daha aktif ve canlı tutmak yoluyla öğrenmenin de etkili ve kalıcı 
olması sağlanmaktadır. Buna yönelik olarak özellikle dil ve edebiyat alanlarının öğretiminde, çoklu öğrenme ortamları ve beceri alanlarına yönelik çalışmaların derinlikli ve tam anlamıyla gerçekleştirilmesi önemli bir gerekliliktir. Dil ve edebiyat öğretimi için bu çoklu ortamlar çeşitli şekillerde sağlanabilir. Bunlardan biri edebî metinlerden beyaz perdeye aktarılan eserleri izletmek ve bunlar üzerinde düşündürmek yoluyla olabilir" (Eskimen 2018b: 195). Derslerde filmlerin etkili olmasının en önemli sebeplerinden birisi, yeni nesillerin görsel medyaya çok aşina olmalarıdır (Luis Alvarez ve diğ., 2004 akt. Birkök, 2008: 6). İzleyiciler sürekli olarak televizyon, video, film gibi her tür görsel medya etkisine maruz kalmaktadırlar. Filmlerde görselliğin yanı sıra, son derece etkin olan ikinci bir bilgi aktarma yolu olan işitsellik de kullanılmaktadır. Ses ile bilgi aktarımı ve eğitim, konuşma, müzik ve bir takım ses efektleri şeklinde olmaktadır. Sinema filmleri aracıllğıyla müziğin de eğitimde kullanılması, hayat boyu kullanılacak olan eleştirel düşünme, problem çözme gibi temel kazanımları sağlayacaktır (White \& McCormack akt. Birkök, 2008: 6). Çoğu kez bu türlerin hepsi birlikte kullanılarak beklenen etki en yüksek seviyeye ulaştırılmaktadır (Birkök, 2008: 6). Öykü anlatmak ve dinlemek insanın en temel gereksinimlerinden biridir. Edebiyat metinleri gibi filmler de bu gereksinimden ortaya çıkar. Bu bağlamda bir film de örneğin bir roman gibi yalnızca öyküler anlatmakla, duyular yaşatmakla ve eğlendirmekle sınırlı kalmıyor, aynı zamanda estetik bir yapıt da olabiliyor. Bu medyanın sanatsal bir ifade biçimi olduğunun kabul edildiğini gösteren en önemli olgulardan biri, filmin anlatım biçimlerine ve estetik yapılarına ilişkin seksen yıldır yürütülen kuramsal çalışmalar ve tartışmalardır (Kayaoğlu, 2016:6). Buna yönelik olarak edebiyat dersleri için edebî metinlerden uyarlanan senaryo ve filmler yoluyla öğrencilerin metni, olay örgüsünü anlayıp anlayamadığının değerlendirmeleri yapılabilir. Bu anlamda edebî metinlerden uyarlanan senaryo ve filmler üzerinde çalışmak öğrencilerin birtakım becerilerinin gelişimine de katkı sağlar. Öztaş (2007), filmlerin geliştirdiği bu birtakım becerileri empati kurma, eleştirel düşünme, yaratıcı düşünme, iletişim kurma, araştırma, problem çözme, zaman ve kronolojiyi algılama, değişim ve sürekliliği algılama, karar verme, görsel okuma olarak ifade eder.

Edebiyat eğitiminde edebî metinlerin film uyarlamaları genel olarak olayların analizi ve olay örgüsünün somutlaştırılmasında, öğrencinin dikkatini çekmede, 
basitleştirme ve dolayısıyla öğrenmeyi kolaylaştırmada oldukça etkilidir. Sinema filmleri, olaylardaki insan boyutunu açıklamakta kullanılabilecek en mükemmel araçlardır. Öğrenciler filmlerde sergilenen karakterleri analiz edebilmekte ve ilgili olaylara ve açıklamalara bağlayabilmektedirler (Birkök, 2018: 8). Nitekim, "Hız ve tüketimin ön planda olduğu günümüz şartlarında edebî eser filmleştirilerek okur ve izleyici için cazip bir hâl almaktadır. Edebî metinlerin sinemaya uyarlanmasında hikâyenin hemen hemen bütün görsel ve kişisel özellikleri somutlaşmakta, olay örgüsünün çözümlenmesi ve metnin incelenmesi de hızlanmaktadır. Bunun bir başka sonucu olarak öğrenme sürecindeki zaman yönünden tasarruf edilmesidir" (Keleş 2017: 172). Sinema filmleri karmaşık bilimsel, sosyal veya edebiyat teorilerini anlamak ve öğretmekte kullanılan çok etkin bir unsurdur. Dekonstrüksiyon gibi yeni yöntemlerle filmler incelenerek yeni edebiyat akımlar1 veya karmaşık bir edebiyat teorisi çözümlenebilmektedir (Muller, 2006 akt. Birkök, 2018: 8). Bunlara paralel olarak, destan türünün öğretiminde filmlerin kullanılmasına yönelik çalışmasında İnce Yakar (2011), edebî metinlerin sinemaya uyarlanmasıyla karakterlerin ve özelliklerinin somutlaştığını, olay örgüsünün çözümlenmesinde ve metnin genel analizinde filmlerin etkili olduğunu belirtir.

Edebiyat film ilişkisini şiir ekseninden hareketle ele alan Cengis Asiltürk (2006), her iki alanın ortaklıklarını ve eğitimsel kazanımlarını şöyle dile getirir: "Duyarlı ve düşünen insan yetiştirmede filmler birer araç olarak kullanılabilir. Şiir ve filmin yaratımı gibi onu anlamlandırabilmek de bilgiden çok, belli bir beceri, belli bir yaratıcılık işidir. Gerçek amaç bunların anlam evrenine girebilmektir. Bu sanatlar, dili iyi kullanabilme, çok boyutlu düşünebilme, kolay iletişim kurabilme yetisi kazandırabilir (s.300).

Bilindiği gibi yazın alanında iletişimi dört ana beceri oluşturur: okuma, dinleme, yazılı anlatım, sözlü anlatım. İşin içine çözümleme isteyen film-yapının girmesi düzgüleri çözebilme, görebilme, anlayabilme, görüntü dilini okuyabilme, gördüklerine de anlamlar yükleyebilme, yani anlamlandırabilme niteliklerini kazandırır. Ezberlenen bilgiler geçici olduğu, ancak genelde birçok sanat yapıtı, özelde de film ve şiir aracıllğıyla sezilen her türlü bilginin zihne yerleşebileceği ve yalnız sezinletilen davranışların insan da kalıcı olabileceği düşünülmektedir (Asiltürk, 2006: 304). 
Edebiyat öğretiminin yanı sıra dil alanına yönelik filmlerin faydaları yine Asiltürk (2006) tarafından şöyle dile getirilir: "Toplumsal açıdan en önemli araçlardan biri olan ve sinemanın olmazsa olmaz gereci durumundaki dil, doğal, en yetkin iletişim aracı olarak insanın toplumsallaşmasını sağlayan önemli etkenlerden biri. Dil, bu yönüyle "Yaşama ilişkin olanın 'kurmaca' olarak canlandırılma biçimi” diye tanımlanan filmlerde çok kullanıldığı için sinema, insanın dilsel açıdan belli deneyimler kazanacağı önemli alanlardan biri olarak değerlendirilebilir. Anadiline bu açıdan bakılırsa, anadilinin önemli ürünlerinden biri olan şiirin dilsel deneyim kazanılacak bir araç olduğu görülür” (s.305).

Dil öğretiminde filmlerin kullanımına yönelik başka bir bakış açısı da şöyledir: "Bir film ait olduğu toplumun kültürel unsurlarını da yansıtır. O topluma ait bireylerin davranış biçimlerini, yaşam tarzlarını, jest ve mimiklerini seyreden kişiye aktarır. Bunların yanında videolar ve filmler dil öğretimi için de kullanılabilecek önemli materyallerin arasında gelirler. Kelimelerin cümle içinde kullanışları, anlamları filmdeki karakterlerin konuşmalarıyla öğretilebilir. Sözcüklerin seslendirilmesi, tonlanması, jest ve mimikler gibi iletişimi kolaylaştıran hareketlerin ve beden dilinin öğrenilmesinde de filmler kullanılabilir" (Özbay, 2009: 192). Birkök (2018), filmlerin dil öğreniminde kullanılmasına yönelik bir uygulama örneğinden hareketle şunları aktarır: Bu uygulamada özel olarak dil eğitimi amaçlayan filmler çevirmek yerine, mevcut bir film 20 dakikalık parçalara ayrılmakta ve içeriğiyle ilgili olarak yazımların, egzersizlerin, dilbilgisi ve kelime bilgilerinin bulunduğu bir kitapçık öğrenciye verilmektedir. Bu yöntem, eğitime uygun tüm yaş grupları için, genel olarak dil öğrenmeden belirli bir sınava hazırlanmaya kadar çok geniş bir amaç yelpazesinde etkili bir şekilde kullanılabilmektedir. Dil öğretmenleri için materyal geliştirmede kullanılan (Kramer, 2004) pek çok başka örnek bulunmaktadır.

Filmlerin dil ve edebiyat öğretiminin yanı sıra farklı alanlarda da örneğin tarih öğretim etkinliklerinde pek çok faydasının bulunduğu Demircioğlu (2007) ve Öztaş $(2010,2014)$ tarafından şöyle ifade edilmiştir:

- Öğrencilerin ilgilerini çekme.

- Değişik tarihi konulara yönelik geniş bir içerik sunma.

- Belirli bir noktayı açık hale getirme.

- Dersi ilginç hale getirme. 
- Öğrencilerin duygularına hitap etme.

- Öğrenciye gösterilen film özetlerinin ardından, gösterimi yapılan konuyu neyin takip edeceğini söyleme imkânı sağlama.

- Öğrencilere, gösterimi yapılan film özeti hakkında kendi el yazılarıyla görüşlerini yazma imkânı sağlama.

- Kavramları görsel olarak sunma.

- Bir olayın iki farklı versiyonunu gösterme.

- Geçmişi ilginç ve ulaşılabilir kılmaya yardımcı olma.

- Öğrencilere diğer şekilde ulaşılması mümkün olmayan kanıt ve kaynaklar sunma.

- Öğrencilere tanımadıkları insanlar ve yerler hakkında açı ve net bir fikir verme.

- Motivasyonu arttrrma.

- İlgi ve merakı arttırma.

- Karmaşık şeyleri basitleştirme.

\section{Yöntem}

\section{Araştırmanın amacı ve önemi}

“Teknolojik ve ekonomik açıdan gelişmiş ülkelerde eğitim ve öğretim etkinliklerinde filmlerin kullanılmasının geçen yüzyılın ilk çeyreğine dayandığı bilinmektedir" (Demircioğlu, 2007: 77). Sağlam bir senaryo, ilginç ve girift bir kurgu, iyi işlenmiş karakterler, güçlü tasvirlerle donanmış mekân ayrıntılarını edebî türden beslenerek kullanan sinema, sanatsal açıdan başarılı bir filme ulaşmaktadır. Şiir, deneme, hikâye ve özellikle de roman gibi edebî türler sinemaya sıkça uyarlanmışlardır (İnce Yakar 2011). Bu anlamda edebiyat ve sinema ilişkisini kavratabilecek derslerin üniversitelerin öğretim programlarında yer alıp almama durumlarını tespit etmek maksadıyla çalışmada Türk Dili Edebiyatı ve Türk Dili ve Edebiyatı Öğretmenliği lisans programlarında sinema, edebiyat ve medyaya yönelik derslere yer verilme durumu ele alınmıştır.

\section{Verilerin toplanması ve analizi}

Araştırma, var olan bir durumu belge incelemeye dayalı bir biçimde betimlediği için nitel veri analizi tekniklerinden yararlanılarak gerçekleştirilen betimsel 
bir çalışmadır. Verilerin toplanmasında doküman incelemesi yapılmıştır. "Doküman incelemesi; araştırılması hedeflenen olgu veya olgular hakkında bilgi içeren yazılı materyallerin analizini kapsar" (Yıldırım ve Şimşek 2008: 187). Çalışma dokümanını, Yükseköğretim Kurulu internet sayfasında yer alan vakıf ve devlet üniversiteleri, 2018- 2019 y1l Türk Dili ve Edebiyatı ve Türk Dili ve Edebiyatı öğretmenliği bologna bilgi sistemi paketi lisans programı dersleri, ders içerikleri oluşturmaktadır. Elde edilen veriler, "doküman incelemesinin beş aşaması olan (1) dokümanlara ulaşma, (2) orijinalliği kontrol etme, (3) dokümanları anlama, (4) veriyi analiz etme ve (5) veriyi kullanma" (Forster, 1995 akt. Yıldırım ve Şimşek 2008: 193) aşamaları takip edilerek değerlendirilmiştir.

\section{Bulgular}

Yükseköğretim Kurulu internet sayfasında vakıf ve devlet olmak üzere Türk Dili ve Edebiyatı Öğretmenliği bölümü olan sekiz üniversite vardır. Bunlar Atatürk Üniversitesi (Kazım Karabekir Eğitim Fakültesi), Balıkesir Üniversitesi (Necatibey Eğitim Fakültesi), Dicle Üniversitesi (Ziya Gökalp Eğitim Fakültesi), Dokuz Eylül Üniversitesi (Buca Eğitim Fakültesi), Gazi Üniversitesi (Gazi Eğitim Fakültesi), Marmara Üniversitesi (Atatürk Eğitim Fakültesi), Necmettin Erbakan Üniversitesi (Ahmet Keleşoğlu Eğitim Fakültesi) ve Van Yüzüncü Y1l Üniversitesi (Eğitim Fakültesi)' dir. Türk Dili ve Edebiyatı öğretmenliği lisans programları içerisinde sinema, edebiyat ve medyaya yönelik seçmeli medya okuryazarlığı dersi tüm lisans programlarında yer almaktadır. Çalışmamıza paralel bir araştırma olan Alper Keleş (2015) tarafından yapılan edebiyat eğitiminde film kullanımına yönelik Alman Dili ve Edebiyatı lisans programlarının araştırıldığı makalede Ege, İstanbul ve Namık Kemal Üniversiteleri Alman Dili ve Edebiyatı bölümlerinde Edebiyat ve Film, Medya Seminerleri I-II-III-IV ile Film Araştırmaları I-II derslerine yer verildiği tespit edilmiştir.

Yükseköğretim kurulu internet sayfasında vakıf ve devlet olmak üzere Türkiye'de iki yüz dört üniversite bulunmaktadır. Bu üniversitelerden Türkiye'de eğitim veren ve normal öğretim olmak üzere yüz on birinde Türk Dili ve Edebiyatı bölümü yer almaktadır. Türk Dili ve Edebiyatı bölümünde sine- 
ma, edebiyat ve medyaya yönelik aşağıda isimleri verilen dersler yer almaktadır. ${ }^{1}$

Tablo 1. Türk Dili ve Edebiyatı lisans programı sinema, edebiyat ve medyaya yönelik dersler

\begin{tabular}{|l|l|}
\hline $\begin{array}{c}\text { Türk Dili ve Edebiyatı Programlarında Sinema, } \\
\text { Edebiyat ve Medyaya Yönelik Dersleri Bulunan } \\
\text { Üniversiteler }\end{array}$ & \multicolumn{1}{c|}{ Dersin Adı } \\
\hline 1. Afyon Kocatepe Üniversitesi & $\begin{array}{l}\text { Sinema ve Edebiyat } \\
\text { İletişim ve Edebiyat }\end{array}$ \\
\hline 2. Aksaray Üniversitesi & Medya Okuryazarlı̆̆ \\
\hline 3. Ankara Sosyal Bilimler Üniversitesi & Edebiyat ve Görsel Sanatlar \\
\hline 4. Bandırma Onyedi Eylül Üniversitesi & $\begin{array}{l}\text { Senaryo Yazım Teknikleri } \\
\text { Edebiyat ve Görsel Sanatlar }\end{array}$ \\
\hline 5. Başkent Üniversitesi & İletişim ve Edebiyat \\
\hline 6. Batman Üniversitesi & Senaryo Yazarlı̆̆1 \\
\hline 7. Bilecik Şeyh Edebali Üniversitesi & İletişim ve Edebiyat \\
\hline 8. Bolu Abant İzzet Baysal Üniversitesi & $\begin{array}{l}\text { İletişim ve Edebiyat } \\
\text { Mit Masal Medya }\end{array}$ \\
\hline 9. Çağ Üniversitesi & $\begin{array}{l}\text { Medya Okuryazarlığ1 } \\
\text { Edebiyat ve Sinema }\end{array}$ \\
\hline 10. Çankırı Karatekin Üniversitesi & Edebiyat ve Sinema \\
\hline 11. Fatih Sultan Mehmet Vakıf Üniversitesi & Edebiyat Medya ve Görsel Sanatlar \\
\hline 12. Gaziantep Üniversitesi & $\begin{array}{l}\text { Edebiyat ve Sinema-I-II } \\
\text { Medya ve Kültür }\end{array}$ \\
\hline 13. Harran Üniversitesi & Sinema ve Senaryo Yazarlığı-I \\
\hline 14. Hitit Üniversitesi & İletişim ve Edebiyat \\
\hline 15. İstanbul Aydın Üniversitesi & Sürdürülebilir Gelişme ve Sinema \\
\hline 16. İstanbul Kültür Üniversitesi & $\begin{array}{l}\text { Edebiyat ve Sinema } \\
\text { Edebiyat ve Güzel Sanatlar }\end{array}$ \\
\hline 17. İstanbul Medeniyet Üniversitesi & Edebiyat ve Görsel Sanatlar \\
\hline 18. İstanbul Üniversitesi & $\begin{array}{l}\text { Edebiyat ve Görsel Sanatlar } \\
\text { Senaryo Yazma Teknikleri }\end{array}$ \\
\hline 19. İstanbul 29 Mayıs Üniversitesi & Edebiyat ve Sinema \\
\hline 20. İstinye Üniversitesi & $\begin{array}{l}\text { Edebiyat, Medya ve Görsel Sanatlar } \\
\text { Senaryo Yazma Teknikleri }\end{array}$ \\
\hline
\end{tabular}

$1 \mathrm{Bu}$ derslerin üniversitelerin bilgi paketinde yer verilen dersler olduğu, çalışmadan sonra gerçekleştirilen herhangi bir güncelleme durumunda değişiklik gösterebileceği ve tabloya yalnızca alan/alan eğitimi seçmeli derslerinin dâhil edildiği ifade edilmelidir. 


\begin{tabular}{|c|c|}
\hline 21. İzmir Kâtip Çelebi Üniversitesi & Edebiyat ve Görsel Sanatlar \\
\hline 22. Kastamonu Üniversitesi & Edebiyat ve Sinema \\
\hline 23. Kırşehir Ahi Evran Üniversitesi & İletişim ve Edebiyat \\
\hline 24. Kütahya Dumlupınar Üniversitesi & Edebiyat, Sinema ve Eğitim \\
\hline 25. Manisa Celâl Bayar Üniversitesi & Sinema ve Halk Bilimi I-II \\
\hline 26. Mardin Artuklu Üniversitesi & Sinema ve Folklor \\
\hline 27. Marmara Üniversitesi & Edebiyat ve Sinema \\
\hline 28. Muğla Sıtkı Koçman Üniversitesi & $\begin{array}{l}\text { Edebiyat ve Sinema } \\
\text { Halk Kültürü ve Sinema }\end{array}$ \\
\hline 29. Mustafa Kemal Üniversitesi & Edebiyat Medya ve İletişim \\
\hline 30. Pamukkale Üniversitesi & $\begin{array}{l}\text { Türkçe ve Yeni Medya } \\
\text { Edebiyat ve Film Uyarlamaları }\end{array}$ \\
\hline 31. Sakarya Üniversitesi & $\begin{array}{l}\text { Tarihsel Filmler } \\
\text { Eğitim Filmleri }\end{array}$ \\
\hline 32. Samsun Ondokuz May1s Üniversitesi & Sinema ve Edebiyat \\
\hline 33. Siirt Üniversitesi & $\begin{array}{l}\text { Edebiyat ve Sinema } \\
\text { Senaryo Örnekleri }\end{array}$ \\
\hline 34. Trakya Üniversitesi & Edebiyat ve Sinema \\
\hline 35. Tobb Ekonomi ve Teknoloji Üniversitesi & $\begin{array}{l}\text { Sinemada Edebiyat Uygulamaları } \\
\text { Eleştirel Film Okumaları } \\
\text { Senaryo Yazarlığı ve Uygulamaları } \\
\text { Reklam Okuryazarlığı }\end{array}$ \\
\hline 36. Uşak Üniversitesi & Yeni Medya ve Mizah \\
\hline 37. Van Yüzüncü Y1l & Edebiyat ve Sinema 1-II \\
\hline 38. Yeditepe Üniversitesi & Popüler Kültür ve Edebiyat \\
\hline 39. Zonguldak Bülent Ecevit Üniversitesi & Edebiyat ve Medya \\
\hline
\end{tabular}

\section{Tartışma, Sonuç ve Öneriler}

Ülkemizdeki gerek ortaöğretim gerekse üniversite dil ve edebiyat öğretimi incelendiğinde, eğitim-öğretim sürecinde derslerde filmlerin ve diğer medya unsurlarının çok yaygın olduğu söylenememektedir. "Pek çok üniversitenin dil ve edebiyat bölümünün ders programında tiyatroya ilişkin derslere yer verilirken, filmle ilgili derslere ancak tek tük rastlanıyor. Oysa normal bir izleme deneyiminin ötesine geçecek ve bilimsellik iddiasında bulunabilecek biçimde filmin an- 
latısal araçlarının ve estetiğinin nasıl ele alınabileceğini bilmek, bir romanın ya da tiyatro oyununun anlatımının nasıl çözülebileceğini bilmenin gerekliliğinden ayrı düşünülemez -özellikle de filmin tüketim bakımından dünyanın bir numaralı anlatma medyası olduğu düşünüldüğünde" (Kayaoğlu, 2016:6).

Dolayısıyla, ortaöğretimden başlanarak öğretim programları ve ders kitapları yoluyla bu durum yaygınlaştııılabilir. Nitekim 2018 yılı Türk Dili ve Edebiyatı dersi öğretim programında da "dersin işlenişinde ve uygulamalarda görsel iletişim araçlarına yer verilmeli; slayt, bilgisayar, televizyon, etkileşimli tahta, Genel Ağ, EBA uygulamaları vb. etkin olarak kullanılmalıdır. Kazanımlarla ilgili belgesel ve film gibi materyallerden yararlanılmalıdır." ifadelerine yer verilir. Üniversite eğitiminden önceki basamak olan lise ders öğretim programlarına eleştirel film okumaları, edebiyat ve sinema, edebiyat ve medya gibi dersler konularak duyup düşündüklerini tartışabilen üniversiteye hazır bireylerin yetişmesi sağlanabilir. Nitekim Sedat Sever (2002 ve 2007)'e göre güzel sanatların olanakları ile edebiyatın anlatım gücünü birleştirmek öğrencilerin düş ve düşünce gücünü; başka bir deyişle, yaratıcılıklarını geliştirir. Bu anlamda çalışmamıza yönelik üniversitelerin de, Türk Dili ve Edebiyatı öğretmeni yetiştiren bireylerin yetiştiği kurumlar olarak, programlarında eleştirel film okumaları, film eleştiri ve analizi, film edebiyatı, edebiyat ve sinema, edebiyat medya ve iletişim vb. derslere daha fazla yer verebileceği ifade edilmelidir. Bu doğrultuda, yukarıda adları sayılan üniversitelerin programlarında sinema, edebiyat ve medyaya yönelik veya bunlarla doğrudan ilgili derslerin kazanımları aşağıdaki gibi sıralanmıştır. Bu dersleri alan öğrenciler,

- Edebiyat ürününe, film tekniklerine, türlerine, film kuramı ve eleştirisine odaklanır,

- Öğrenciler bir filmi, kültürel ve farklı eleştirel yaklaşımlarla analiz eder birer metin biçiminde izlemeyi öğrenir,

- Edebiyat ve görsel sanatların, sinemanın benzer ve farklı yönlerini keşfeder,

- Edebiyat ile sinema arasındaki ilişkiyi, bu iki alanın etkileşimini, edebiyattan uyarlanan senaryo ile filmleri karşılaştırır,

- Edebiyattan uyarlanan filmleri analiz eder, 
- Sinemaya aktarılan edebiyat eserlerinden hareketle yapılan örnek uyarlamaları yakından tanır, buna yönelik çözümlemeler yapar,

- Edebî eserlerin (roman-hikâye-mesnevi) hangi değişkenlerden geçerek senaryo hâline getirildiğini öğrenir,

- Öyküleme tekniklerini kullanarak, bu senaryonun dramatik yapısının nasıl kurgulandığını uygulamalı olarak öğrenir,

- Görsel düşünmeyi ve izledikleri bir filmin senaryosu ve senaristi hakkında fikir yürütebilmeyi öğrenir. Buna yönelik olarak yorumlama ve yazma denemeleri gerçekleştirir. Kimi yazarların sinema hakkındaki fikirlerini yorumlar,

- Filmleri içerik ve biçimleriyle analiz edebilmek ve değerlendirebilmek için filmleri birer eğlence aracı olarak görmekten farklı dönem ve temalardaki filmlerin analizinden yola çıkılarak eleştirel düşünme becerisi kazanır. Böylece filmleri sosyal ve kültürel etki ve etkileşimleriyle daha derinlikli katmanlarıyla kavrar, değerlendirir,

- Film kuramları, film yapım süreçleri, film dili ve biçimi, filmlerin birer görsel metin olarak ne şekilde içerik analizlerinin yapılabileceği ve filmlerin eleştirel okumalarının nasıl gerçekleştirileceği hususlarında fikir sahibi olur, farkındalık geliştirir.

Farklı lisans programlarına yönelik başka çalışmalar gerçekleştirilebilir.

Edebiyat sinema ilişkisinin yanı sıra bunların eğitim alanında kullanımına ilişkin çalışmalar yapılabilir. 


\section{Kaynaklar}

Akbayır, Sıddık (2014), Edebiyat ve Disiplinler Arası Etkileşim, Ankara: Pegem Akademi.

Arıkan, Arda (2009), "Edebiyat Öğretiminde Görsel Araç Kullanımı: Kısa Öykü Örneğì, Ondokuz Mayıs Üniversitesi Eğitim Fakültesi Dergisi, 27, s. 1-16.

Asiltürk, Cengis (2006), Sinemada Şiirsel Anlatım, Ankara: Nobel Yayın Dağıtım.

Aytaç, Gürsel (2005), Edebiyat ve Medya (Kitaptan Ekrana Edebiyat), Ankara: Hece Yayınları.

Birkök, Mehmet Cüneyt (2008), "Bir Toplumsallaştırma Aracı Olarak Eğitimde Alternatif Medya Kullanımı: Sinema Filmleri”. Uluslararası Insan Bilimleri Dergisi, C.5, S.2, s. 1-12.

Çetin, Zeynep (1999), Bir Anlatı Formu Olan Romanın Sinemaya Uyarlanması. Doktora Tezi, İstanbul: Marmara Üniversitesi Radyo-Televizyon ve Sinema Ana bilim Dalı.

Demirel, Özcan (1993), Yabancı Dil Öğretimi İlkeler Yöntemler Teknikler, Ankara: Usem Yayınları.

Demircioğlu, İsmail Hakkı (2007), “Tarih Öğretiminde Filmlerin Yeri ve Önemi”. bilig, 42, s. 77-93.

Ekici, Savaş (2004), “Popüler Kültür'ün İcra Ortamı Bağlamında Medya - Türk Halk Müziği İlişkisine Dair Bazı Tespit ve Öneriler”, TÜBAR, XVI, s.181-189.

Eskimen, Ayşe Derya (2018a), "Using, Films In Teaching Of Language And Literature In Secondary Education Level”, (Ed. Turhan Çetin ,Ayfer Şahin, Almasa Mulalic, Nudjezma Obralic), New Horizons in Educational Sciences-II, s. 195-206, Riga.

Eskimen, Ayşe Derya (2018b), "Edebiyat Öğretimi ve Sinema- Bir Film İzleme Etkinliği”, Bilkent Üniversitesi XIII. Uluslararası Büyük Türk Dili Kurultayı Bildirileri Kitab1, 2528 Eylül 2018,Polonya-Varşova, Meteksan Matbaacılık ve Teknik Sanayi Ticaret A.Ş.

İnce Yakar, Halide Gamze (2011), Destanların Öğretiminde Film Kullanımının Ortaöğretim Türk Edebiyatı Derslerindeki Akademik Başarıya Etkisi, Ankara: Gazi Üniversitesi, Eğitim Bilimleri Enstitüsü, Yayınlanmamış doktora tezi.

İnce Yakar, Halide Gamze (2017), “Türk Dili ve Edebiyatı Öğretmenlerinin Eğitim Amaçlı Sinema Filmi Kullanım Yöntemleri”, Akademik Sosyal Araştırmalar Dergisi, S. 62, s. 190-205.

Kaçar Gitmez, Songül (1999), “Küreselleşen Dünyamızda Medya ve Kültür”, Folklor ve Edebiyat Dergisi, S.15, s.19-29.

Kaşkaya, Alper ( 2013), Okul ve Öğretmen İçerikli Sinema Filmlerinin Öğretmen Adaylarının Pedagojik İnançları ve Eleştirel Yansıtma Becerileri Üzerine Etkisi, Ankara: Gazi Üniversitesi, Eğitim Bilimleri Enstitüsü, Yayınlanmamış doktora tezi. 
Kayaoğlu, Ersel (2016), Edebiyat ve Film Edebiyat Bilimi Yaklaşımıyla Film Çözümlemesine Giriş, İstanbul: Hiperlink Yayınları.

Keleş, Alper (2015), "The Role of Films in Literature Education at Departments of German Language and Literature in Turkey", Procedia - Social and Behavioral Sciences, s. 652-658.

Keleş, Alper (2017), “ Medyalararası Bir Yaklaşımla Uyarlama Filmler ve Edebiyat Öğretimi”, Sosyal ve Kültürel Araştırmalar Dergisi, C. III, S. 6, s. 165-176.

Kocadaş, Bekir (2006), “Kültür ve Medya”, Uluslar Arası İnsan Bilimleri Dergisi, S. 1, s. 1-8.

Millî Eğitim Bakanlığı (2018), Ortaöğretim Türk dili ve edebiyatı dersi (9, 10, 11 ve 12. sınıflar) öğretim programı. http://mufredat.meb.gov.tr/ProgramDetay.aspx?PID=353

Özbay, Murat (2009), Türkçe Özel Öğretim Yöntemleri I. Ankara: Öncü Kitap.

Özdemir, Nebi (2012), Medya Kültür ve Edebiyat, Ankara: Grafiker Yayınları.

Öztaş, Sezai (2007), Tarih Öğretimi ve Filmler: Tarih Öğretiminde Film Kullanılmasının Öğrenci Başarısı Üzerine Etkisi, Ankara: Gazi Üniversitesi, Eğitim Bilimleri Enstitüsü, Yayınlanmamış doktora tezi.

Sever, Sedat (2007), “Türkçe Öğretiminde Sanatsal Bir Uyaran Olarak Karikatürün Kullanılması”, VI. Ulusal Sınıf Öğretmenliği Eğitimi Sempozyum Kitapçı̆̆ı, 27-29 Nisan 2007, Anadolu Üniversitesi, Eskişehir, Ankara: Nobel Yayın Dağıtım.

Sever, Sedat (2002), “Öğretim Dili Olarak Türkçenin Sorunlan ve Öğretme-Öğrenme Sürecindeki Etkili Yaklaşımlar”, Ankara Üniversitesi Ĕ̆itim Bilimleri Fakültesi Dergisi, C.34, S. 1-2, 11-22.

Uğurlu, Faruk (1992), Edebiyat ve Sinema, eKurgu Anadolu Üniversitesi İletişim Bilimleri Fakültesi Dergisi, C.11, S. 1, S. 135-151.

Vardar, Bülent (2012), Sinema ve Televizyon Görüntüsünün Temel Öğeleri, İstanbul: Beta Yayincilik.

Yüce, Tuncay (2005), Sinema ve Edebiyat Türleri Arasında Görülen Etkileşimler, ZKÜ Sosyal Bilimler Dergisi, Cilt 1, Say1 2, s. 67-74. 